\title{
PENGGUNAAN MODEL STAD BERBASIS PRAKTIKUM UNTUK MENINGKATKAN HASIL BELAJAR IPA PADA SISWA KELAS 5 SDI WATUJARA
}

\author{
${ }^{1}$ Nining Sariyyah, ${ }^{2}$ Adi Neneng Abdullah, ${ }^{3}$ Yuliani Sepe Wangge \\ ${ }^{123}$ Prodi PGSD Universitas Flores Ende \\ Email: sariyyah.nining@gmail.com
}

\begin{abstract}
Abstrak
Penelitian ini bertujuan untuk meningkatkan hasil belajar IPA pada siswa kelas V SDI Watujara. Jenis penelitian ini adalah penelitian tindakan kelas. Subyek penelitian merupakan siswa kelas V SDI Watujara yang berjumlah 27 orang. Data dikumpulkan dengan teknik tes, catatan lapangan dan wawancara. Data kemudian dianalisis dengan membandingkan persentase ketuntasan minimal secara klasikal pada setiap akhir siklus. Hasi penelitian menunjukkan terdapat peningkatan hasil belajar siswa setelah diterapkan model STAD berbasis praktikum.
\end{abstract}

Kata kunci: Model, STAD, Hasil Belajar

A. Latar Belakang

Pendidikan merupakan upaya untuk membentuk sumber daya manusia yang dapat meningkatkan kualitas kehidupannya. Salah satu wadah dalam pembentukan kualitas sumber daya manusia adalah melalui proses pendidikan. Karena itu, peningkatan mutu pendidikan merupakan hal yang wajib dilakukan secara berkesinambungan guna menjawab perubahan zaman. Masalah peningkatan mutu tentulah sangat berhubungan dengan masalah proses pembelajaran.
Setiap proses pembelajaran memiliki keunikan yang mnjadi ciri khas dari ilmu pengetahuan tersebut. Proses pembelajaran IPA pada hakekatnya merupakan pengetahuan berdasarkan fakta, hasil pemikiran dan produk hasil penelitian. Perkembangan IPA dalam pendidikan diarahkan pada produk ilmiah, metode ilmiah dan sikap ilmiah yang dimiliki siswa dan akhirnya bermuara pada perubahan proses belajar. Kemampuan siswa dalam bidang IPA merupakan salah satu kunci keberhasilan peningkatan kemampuan dalam memasuki 
dunia teknologi. Menurut Youl (dalam Kumara, 2004), persaingan sains di masa depan sebenarnya tidak dilihat dari berapa besar penguasaan sains oleh suatu negara saat ini, tetapi justru terletak pada usaha mempersiapkan anak-anak agar "melek"sains sejak awal.

Untuk mempersiapkan peserta didik menjadi melek sains diperlukan proses pembelajaran IPA dimana siswa dapat mengkonstruksi pengetahuan sendiri. Melalui proses tersebut, diharapkan siswa dapat menghubungkan pengetahuan yang dimiliki dengan pengetahuan baru yang diperoleh (Nurajizah, Windyariani, Setiono, 2018). Proses tersebut dapat dilakukan melalui kegiatan-kegiatan praktikum. Namun pada kenyataannya, praktikum masih jarang dilakukan di sejumlah sekolah di Indonesia dengan alasan tidak memiliki laboratorium, guru tidak memiliki pengetahuan tentang proses praktikum, praktikum kurang efektif dan menyita alokasi waktu pembelajaran dan lain sebagainya. Fakta ini salah satunya ditemukan dalam proses pembelajaran IPA di kelas V SDI Watujara Ende.

Berdasarkan hasil pengamatan dalam proses pembelajaran IPA di kelas V SDI
Watujara Ende masih dilakukan secara tradisional. Pemahaman materi seperti sifat-sifat cahaya tidak diperkenalkan melalui kegiatan praktikum. Proses belajar dilakukan dengan ceramah yang terfokus pada buku paket. Pemberian contoh dilakukan dengan mengamati gambar-gambar dua dimensi sederhana. Gambaran pembelajaran ini berdampak terhadap rendahnya pemahaman konsep siswa dimana masih banyak siswa yang belum mencapai kriteria ketuntasan minimum.

Beberapa masalah yang telah diuraikan tersebut membutuhkan perbaikan pada proses pembelajaran yang diharapkan mampu berdampak pada hasil belajar siswa. Persoalan di atas dapat ditangani dengan mengganti prosedur pembelajaran di kelas. Antara lain mengganti strategi pembelajaran yang diterapkan. Salah satu alternatifnya adalah dengan menerapkan model STAD berbasis praktikum.

Model STAD merupakan salah satu tipe dari model pembelajaran kooperatif dengan menggunakan kelompok-kelompok kecil dengan jumlah anggota tiap kelompok 4-5 orang peserta didik secara heterogen yang merupakan campuran menurut tingkat prestasi, 
jenis kelamin, dan suku (Slavin dalam Rusman, 2012: 213). Praktikum adalah metode dimana dalam proses belajar mengajar guru menekankan pada siswa untuk menemukan sendiri informasi yang bertujuan mengajarkan keterampilan menyelidiki dan memecahkan masalah sebagai alat bagi siswa untuk mencapai tujuannya (Suryosubroto dalam Agustina, 2015). Berdasarkan defenisidefenisi tersebut, model STAD berbasis praktikum adalah suatu model pembelajaran menggunakan kelompok-kelompok kecil heterogen yang menekankan pada kegiatan penyelidikan dan pemecahan masalah untuk menjawabi tujuan pembelajaran.

Penelitian relevan tentang model STAD berbasis praktikum pernah dilakukan Ariningsih (2007), Lina (2012) dan Ewo (2009). Hasil penelitian ketiganya membuktikan model STAD berbasis praktikum dapat meningkatkan hasil belajar siswa. Merujuk pada permasalahan, kajian teoritik dan penelitian serupa, maka dilakukan penelitian dengan menerapkan model STAD berbasis praktikum untuk mengatasi rendahnya hasil belajar IPA pada siswa kelas V SDI Watujara Ende.
B. Metode Penelitian

Penelitian ini merupakan penelitian tindakan kelas yang menggunakan rancangan Kemmis Taggart. Prosedur penelitian ini terdiri atas tahapan perencanaan, tahapan tindakan, tahapan observasi dan tahapan refleksi yang dilakukan secara siklik. Subyek penelitian merupakan siswa kelas V SDI Watujara yang berjumlah 27 orang dan terdiri dari 11 orang laki-laki dan 16 orang perempuan. Data utama dikumpulkan dengan teknik tes. Sedangkan data pendukung lain diambil melalui catatan lapangan dan wawancara. Data kemudian dianalisis dengan membandingkan persentase ketuntasan minimal secara klasikal pada setiap akhir siklus. Apabila 90\% siswa telah mencapai KKM, maka tindakan berhasil dilakukan sehingga tidak perlu dilanjutkan ke siklus berikutnya.

\section{Hasil dan Pembahasan Hasil Penelitian}

Penelitian ini dilaksanakan dalam dua siklus dengan menerapkan model STAD berbasis praktikum pada materi cahaya di kelas V SDI Watujara. Siklus 1 terdiri atas tiga kali pertemuan sedangkan siklus 2 dilakukan dalam dua kali pertemuan yang 
melalui prosedur perencanaan, tindakan, observasi dan refleksi.

Tahap

perencanaan

dilakukan peneliti dengan mempersiapkan perangkat pembelajaran dengan model STAD berbasis praktikum serta alat dan bahan praktikum tentang cahaya. Setelah persiapan matang, dilakukanlah tahap tindakan. Dalam penelitian ini peneliti berperan sebagai partisipan sebagian. Peneliti tidak mengajar melainkan dibantu oleh guru kelas $\mathrm{V}$ untuk melaksanakan penerapan model STAD berbasis praktikum di kelas V SDI Watujara. Proses penerapan model STAD berbasis praktikum melalui langkahlangkah sebagai berikut:

1. Guru memberikan pre test untuk penentuan skor perkembangan individu

2. Guru memberikan gambaran materi dan kegiatan belajar yang akan dilaksanakan

3. Siswa dibagi ke dalam lima kelompok berdasarkan perbedaan prestasi belajar dan jenis kelamin

4. Setiap kelompok melakukan praktikum dan menuliskan hasil praktikum

5. Presentasi laporan praktikum

6. Guru memberikan Post test

7. Guru memberikan reward

Selama proses tindakan berlangsung peneliti bersama rekan sejawat lain mengobservasi dan mendokumentasikan proses pembelajaran. Hasil observasi dan perolehan hasil belajar dapat dilihat pada Tabel 1

Tabel 1 Hasil Observasi dan Hasil Belajar Penerapan Model STAD berbasis Praktikum

Siklus I

Siklus II

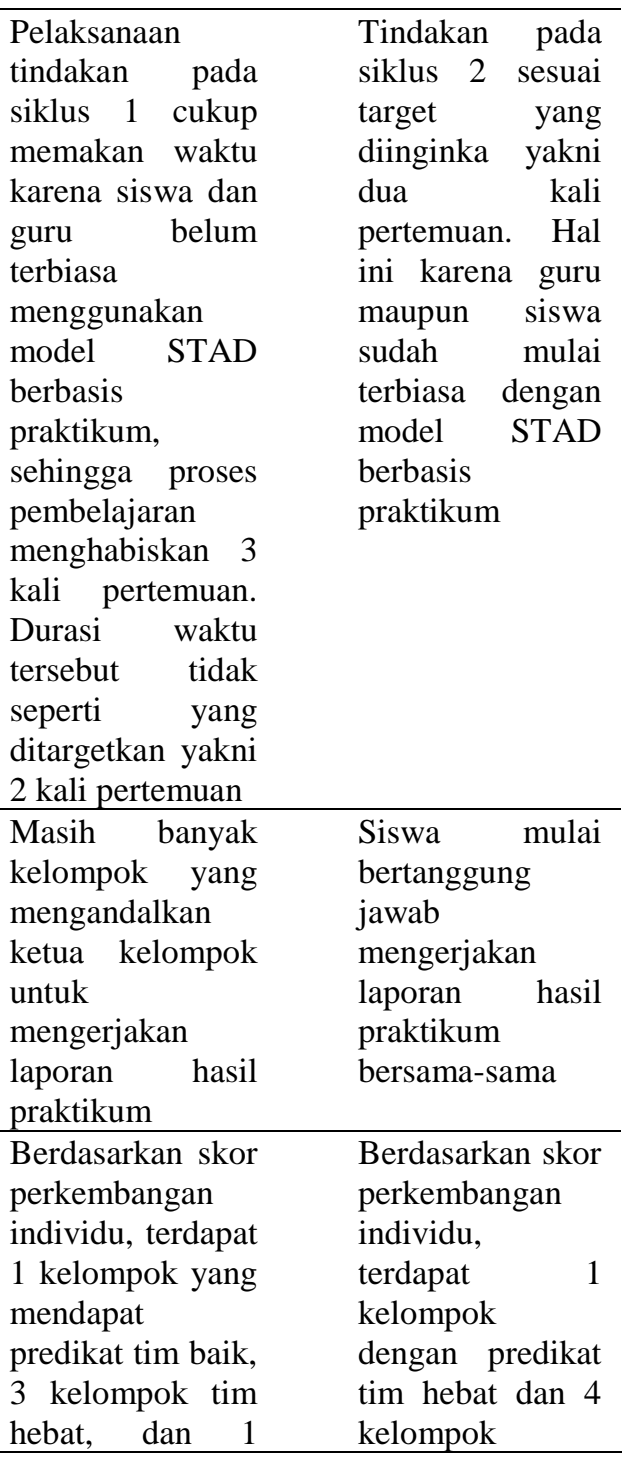




\begin{tabular}{|c|c|}
\hline $\begin{array}{l}\text { kelompok tim } \\
\text { super. }\end{array}$ & $\begin{array}{l}\text { mendapat } \\
\text { predikat tim } \\
\text { super }\end{array}$ \\
\hline $\begin{array}{l}\text { Persentase } \\
\text { ketuntasan } \\
\text { klasikal } \\
\text { mencapai } 67 \% \\
\text { atau } 18 \text { dari } 27 \\
\text { orang siswa telah } \\
\text { mencapai KKM }\end{array}$ & 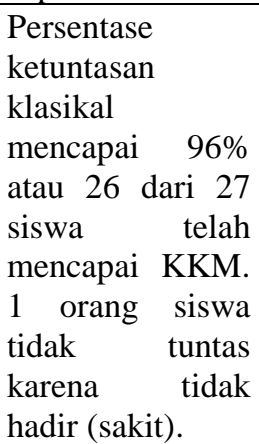 \\
\hline
\end{tabular}

Berdasarkan data persentase pada Tabel 1 direfleksikan hal-hal sebagai berikut:

1. Ditemukan kelemahan dalam efektifitas waktu dalam siklus 1 yakni kegiatan belajar menghabiskan tiga kali pertemuan. Hal ini tidak sesuai dengan target peneliti yakni dua kali pertemuan. Setelah direfleksikan dalam langkah pembagian kelompok cukup menyita waktu pembelajaran. Untuk mengatasi itu, pada siklus II guru terlebih dahulu menata ruang kelas sesuai pola belajar kooperatif. Guru juga menyiapkan papan nama kelompok sehingga proses pembagian kelompok berjalan lebih kondusif pada siklus kedua.

2. Masih banyak kelompok yang mengandalkan ketua kelompok untuk menyelesaikan laporan praktikumnya saat siklus 1 . Untuk mengatasi hal tersebut, guru memberikan arahan dan motivasi agar siswa lebih kompak mengerjakan laporan praktikum. Bagi kelompok yang kompak akan diberi reward tambahan. Pemberian motivasi tersebut membuat siswa lebih bertanggung jawab bersama-sama mengerjakan laporannya.

3. Persentase ketuntasan belajar pada siklus 1 masih $67 \%$ secara klasikal. Hal ini belum sesuai target penelitian yakni 90\%, sehingga dilanjutkan siklus ke 2. Sedangkan pada siklus 2, persentase ketuntasan telah mencapai $96 \%$ sehingga penelitian dihentikan pada siklus 2 karena telah memenuhi target. Dengan demikian model STAD berbasis praktikum dapat meningkatkan hasil belajar siswa kelas V SDI Watujara Ende.

Uraian di atas menunjukkan bahwa model STAD berbasis praktikum dapat meningkatkan hasil belajar IPA. Melalui Model STAD berbasis praktikum siswa dapat membangun konsep sendiri serta dapat berinteraksi secara sosial di dalam tim. Siswa juga dapat saling aktif dan dapat belajar dari siswa lain yang teah mengerti. Sehingga rasa malu bertanya terhadap materi yang belum dimengerti menjadi berkurang. Dalam suasana seperti itu, siswa dapat belajar lebih baik 
dan sungguh-sungguh. Seperti yang disampaikan Miarso (Karyanti, 2016:14) bahwa pembelajaran merupakan usaha mengelola lingkungan dengan sengaja agar seseorang membentuk diri secara positif tertentu dalam kondisi tertentu. Model STAD berbasis praktikum memberikan hal positif terhadap peningkatan hasil belajar siswa.

\section{Kesimpulan dan Saran}

Berdasarkan hasil penelitian ditemukan bahwa terjadi peningkatan hasil belajar IPA pada siswa kelas V SDI Watujara setelah diterapkan model STAD berbasis praktikum. Peningkatan tersebut sebesar $67 \%$ pada siklus 1 menjadi $96 \%$ pada siklus 2 .

\section{Daftar Pustaka:}

Agustina, P. (2015). Persepsi Mahasiswa Calon Guru Biologi tentang Pengembangan Praktikum Biologi Sekolah Menengah: Studi Pengembangan Pembelajaran pada Mahasiswa Pendidikan Biologi FKIP Universitas Muhammadiyah Surakarta. Jurnal Penelitian. Bioedukatika, Vol.3 No.2. Tersedia: https//:scholar.google.co.id
Ariningsih, H.D. (2007). Pengaruh Metode Kooperatif (Student Team Achievement Division dan Team Assisted Individualization) yang Dimodifikasi dengan Praktikum dengan Memperhatikan EQ. Skripsi. Tersedia: eprints.uns.ac.id

Ewo, M.E. (2009). Penerapan pembelajaran kooperatif Model STAD berbantuan bahan Manipulatif yang dapat meningkatkan pemahaman konsep penjumlahan dan pengurangan pecahan pada siswa SD kelas IV. Thesis. Tersedia: library.um.ac.id

Karyanti, R. 2016. Penerapan Pembelajaran Kooperatif Tipe STAD Untuk Meningkatkan Keterampilan Proses Sains dan Prestasi Belajar pada Materi Asam Basa Kelas XI IPA SMAN 1 Kibang. Thesis. Tersedia: digilib.unila.ac.id

Kumara, A.. (2004). Model pembelajaran "active learning" Mata Pelajaran Sains Tingkat SD Kota Yogyakarta Sebagai Upaya Peningkatan "life skills". JURNAL PSIKOLOGI, NO. 2, 63 - 91. Universitas Gadjah Mada. Tersedia: https//:scholar.google.co.id 
Lina, P. (2012). Efektifitas metode Praktikum dengan Alat Peraga Periskop Sederhana Pelajaran IPA terhadap Kreatifitas Siswa Kelas V SD Kanisius Cungkup Kecamatan Sidorejo Kota Salatiga. Skripsi. Tersedia: repository.uksw.edu

Nurajizah, Windyariani, Setiono. (2018). Improving Students' Metacognitive Awareness
Through Implementing

Learning Journal. JPBI (JURNAL PENDIDIKAN BIOLOGI INDONESIA), $V o l$. 4 No. 2, 2018; pp. 105-112. Tersdia:

http://ejournal.umm.ac.id/index .php/jpbi

Rusman, (2012). Model-Model Pembelajaran.Jakarta: PT Rajagrafindo Persada 